\title{
Peer Feedback untuk Mengembangkan Kegiatan Menulis Bahasa Jepang di Kelas Menulis Bahasa Jepang (Sakubun)
}

\author{
Linna Meilia Rasiban*1, Ahmad Dahidi², Susi Widianti ${ }^{3}$ \\ Departemen Pendidikan Bahasa Jepang \\ Universitas Pendidikan Indonesia \\ linnameilia@upi.edu \\ ahmaddahidi@upi.edu \\ w_susiwidianti@yahoo.cp.jp.
}

\begin{abstract}
The purpose of this study was to develop the quality of writing in middle-level Japanese language. From the results of the previousl questionnaires distributed, $80 \%$ of students found it difficult to develop story ideas into complete writing. The difficulty factor is influenced by the lack of time to develop ideas, beside that internal factors, namely mastery of vocabulary, mastery of sentence pattern structure. This study lasted for one semester at an university in Bandung, West Java, Indonesia with 20 students enrolled in writing classes at semesters 4. The students at the lower proficiency level reviewed peer texts. To examine gains in writing quality, a comparative analysis was conducted on writing samples collected at the beginning and the end of the semester. A questionnaire survey was also conducted to investigate the students' perceptions $t$ of assignments. The findings in this study that the students' results needed to be feedback and evaluation to improve the ability to write Japanese short essays. Therefore, for further research will need to apply peer feedback from peer tutors and evaluation from the teacher itself in order to improve writing skills in writing quality.
\end{abstract}

Keywords: peer feedback, writing, essays, evaluation

Abstrak. Tujuan dari penelitian ini adalah untuk mengembangkan kualitas tulisan di tingkat menengah bahasa Jepang. Dari hasil penyebaran kuesioner sebelumnya, $80 \%$ siswa mengalami kesulitan untuk mengembangkan ide cerita menjadi tulisan lengkap. Faktor 
kesulitan dipengaruhi oleh kurangnya waktu untuk mengembangkan gagasan, selain itu faktor internal, yaitu penguasaan kosakata, penguasaan struktur pola kalimat. Penelitian ini berlangsung selama satu semester di sebuah universitas di Bandung, Jawa Barat, Indonesia dengan 20 siswa yang terdaftar di kelas menulis pada semester 4. Para siswa pada tingkat kemahiran yang lebih rendah memberi umpan balik pada tulisan rekannya, Untuk menguji isi dalam kualitas menulis, analisis komparatif dilakukan pada menulis karangan yang dikumpulkan pada awal dan akhir semester. Survei kuesioner juga dilakukan untuk menyelidiki persepsi siswa tentang tugas tersebut. Temuan dalam penelitian ini menunuukkan bahwa hasil tulisan mahasiswa perlu diberi umpan balik dan evaluasi untuk meningkatkan kemampuan menulis esai pendek bahasa Jepang. Oleh karena itu, untuk penelitian lebih lanjut perlu menerapkan umpan balik rekan dari tutor sebaya dan evaluasi dari guru itu sendiri untuk meningkatkan keterampilan menulis dalam menulis kualitas.

Kata Kunci : peer feedback, menulis, sakubun, evaluasi

\section{Pendahuluan}

Menulis adalah salah satu keterampilan produktif, di samping berbicara, yang berisi simbol (ortografi) dan melibatkan proses yang kompleks. Ini adalah bagian dari kemampuan bahasa yang tidak terpisahkan dari keterampilan lainnya yaitu membaca, mendengarkan, dan berbicara(Mubarok, 2012:163). Begitu pula menulis merupakan salah satu keterampilan berbahasa selain dari membaca, mendengar, dan berbicara. Menulis merupakan padanan kata dari mengarang yaitu keseluruhan rangkaian kegiatan seseorang mengungkapkan gagasan dan menyampaikannya melalui bahasa tulis kepada pembaca untuk dipahami" (Gie, 1992:17; Tarigan, 2008:3). Dalam kegiatan menulis, produksi kata-kata tertulis yang hasilnya adalah sebuah teks tetapi teks harus dibaca dan dipahami agar komunikasi berlangsung (Celce-Murcia \& Olstain, 2000:142).

Keberhasilan utama dari seorang guru menulis mungkin berasal dari kemampuannya untuk membuat dan mengembangkan bahan tulis, media pembelajaran, dan strategi yang tepat yang sesuai dengan kebutuhan siswa dan minat (Mubarok, 2012:163). Sistem pengajaran yang masih monoton, tidak ada tantangan, tidak adanya pembelajaran yang bervariasi, 
dan proses pembelajaran tidak menciptakan suasana berkompetisi antar mahasiswa yang pada akhirnya menyebabkan rendahnya kemampuan menulis mahasiswa secara umum (Bistari B.S. dkk, 2001). Pembelajaran menulis harus diarahkan kepada kemampuan penguasaan bahasa Jepang secara kreatif dan berfikir logis dalam berbicara dan menulis. Pembelajaran menulis harus mengajak anak didik untuk menggunakan bahasa dalam segala bentuk dan variasinya. Pembelajaran menulis tidak semata-mata untuk keterampilan komunikasi saja, tetapi juga untuk berfikir kreatif dan logis (Amanda, 2013). Hal inilah yang membuat menulis sulit sekali dikembangkan oleh mahasiswa.

Dari hasil observasi yang dilakukan di siklus pertama pada penelitian sebelumnya (Rasiban, 2014) pada responden yang level kemampuannya sama yaitu mahasiswa semester 4 pun menunjukkan hal yang sama. Walaupun mahasiswa telah diberi tema kemudian distimulus dengan memberikan latihan pola kalimat yang akan muncul pada karangan/ tulisan, lalu diberikan kerangka karangan/berpikir, tetap saja isi tulisan / karangan apabila tidak dipaksakan, tidak bisa berkembang (Rasiban, 2014).

Dalam proses menulis, khususnya menulis karangan, mahasiswa yang memiliki keterbatasan ide akan merasa kesulitan untuk menulis. Kesulitan yang dialami siswa mencakup kesulitan untuk memunculkan ide awal, merangkai kata dan menghidupkan gagasan dalam sebuah tulisan.

Seperti pada penelitian Sutjiati \& Rasiban (2015) menunjukkan bahwa kegiatan menulis dengan menggunakan model pembelajaran ProjectBased Learning (PBL) sangat berkontribusi dalam mengembangkan ide dan kreativitas mahasiswa. Produk tulisan yang dihasilkan pun beragam serta ide dari setiap tema yang dikembang pun bervariasi. Hal ini yang menunjukkan bahwa dengan suatu teknik / strategi yang tepat dapat meningkatkan kemampuan menulis peserta didik.

Berdasarkan hasil studi pendahuluan yang telah dipaparkan di atas bahwa ada berbagai macam masalah yang dialami oleh mahasiswa dalam menulis karangan, salah satunya adalah sulitnya mendapatkan ide 
dan mengembangkannya. Oleh karena itu penerapan model pembelajaran PBL (Project-Based Learning) untuk meningkatkan kemampuan menulis karangan bahasa Jepang dan mempermudah siswa untuk mengeluarkan ide dan mengembangkannya ke dalam sebuah karangan yang baik.

Seperti yang telah dilakukan pada penelitian sebelumnya, apabila dibuat situasi memaksa mahasiswa untuk menghasilkan sebuah karya tanpa ada perasaan terpaksa, yaitu dengan memberikan pembelajaran berbasis proyek (project-based learning), mahasiswa mampu mengembangkan ide dan tulisannya.

Walaupun model pembelajaran PBL ini berhasil dalam mengembangkan ide mahasiswa dalam tema dan isi tulisannya, ada beberapa temuan yang ditemukan pada penelitian ini yaitu kemampuan mahasiswa dalam menuliskan kalimat panjang dan majemuk dinilai sangat kurang. Hal ini dikarenakan kemampuan penguasaan tata bahasa dan pola kalimat serta perbendaharaan kosa kata yang dimiliki mahasiswa masih kurang (Sutjiati \& Rasiban, 2016).

Berdasarkan hasil analisis data yang dilakukan pada penelitian sebelumnya (Sutjiati \& Rasiban, 2016) menunjukkan bahwa mayoritas mahasiswa semester 4 Departemen Pendidikan Bahasa Jepang (DPBJ) FPBS UPI tahun akademik 2014/2015 kemampuan menguasai pola kalimat dan tata bahasa bahasa Jepang tingkat menengah masih kurang. Dan perbendaharaan kosa kata yang dimilikinya pun sedikit.

Tetapi ada hal yang harus diperhatikan bahwa agar kegiatan tersebut dapat berkembang dan terarah perlu adanya kontrol dan evaluasi dari pengajar yaitu dengan memberikan respon berupa evaluasi dan feedback untuk mengembangkan daya kreatifitasnya. Maka lahirlah model pembelajaran Proyek Respon Kreatif untuk menyempurnakan model pembelajaran sebelumnya.

Berdasarkan hasil penelitian tersebut (Rasiban, 2015) menunjukkan bahwa model pembelajaran berbasis Proyek Respon Kreatif dapat membantu dan mempermudah responden dalam mengembangkan ide dan kreatifitas dalam kegiatan menulis terutama dalam proses membuat 
sebuah tulisan baik berupa karangan, memo, surat, email ataupun poster. Mayoritas responden menyatakan ada perkembangan terhadap kegiatan menulis sakubun yang dibuat setelah mendapatkan proyek yang bertahap dalam mengerjakan sebuah tulisan. Karena berbentuk proyek (proyekbased learning), permasalahan yang ditemui pada siklus pertama dapat diatasi, yaitu hampir seluruh jumlah responden tidak mengalami kesulitan dalam mengembangkan idea atau gagasan ke dalam suatu karangan utuh. Hampir setengah dari jumlah seluruh responden merasa bahwa model pembelajaran berbasis Proyek Respon Kreatif menarik ketika diterapkan dalam perkuliahan sakubun karena dapat mengetahui letak kesalahan pada karangan dan dapat secara langsung memperbaikinya.

Tetapi ada beberapa temuan yang didapat pada penelitian ini bahwa kegiatan umpan balik (feedback) yang diberikan oleh pengajar tidak dapat diberikan secara maksimal. Hal ini dikarenakan kegiatan tersebut dilakukan melalui dunia maya / online. Sedangkan pada dunia maya selalu saja dihantui oleh permasalahan koneksi internet yang tidak maksimal, sehingga komunikasi antar pengajar dan peserta didik terhambat kemudian kegiatan feedback pun tidak dapat dilakukan dengan baik. Untuk mengatasi hal ini, muncullah pertanyaan tentang apa yang akan menjadi pendekatan yang paling efektif untuk meningkatkan kemampuan menulis siswa dan pendekatan apa yang akan cocok dengan kebutuhan peserta didik tertentu. Selama dua puluh tahun terakhir, studi pendidikan bahasa telah memberikan perhatian besar pada masalah bagaimana untuk memberikan umpan balik (feedback) untuk menulis siswa (Saito, 1994:46). Memberikan feedback tertulis yang efektif adalah salah satu tugas yang paling penting untuk guru menulis bahasa Inggris (Hyland, 1998; Hyland \& Hyland, 2001).

Banyak penelitian telah menunjukkan bahwa kegiatan feedback yang diberikan oleh pengajar dapat mengembangkan kegiatan menulis peserta didik (Ferris \& Roberts, 2001; Ferris, 2004; Goldstein, 2004; Zhang, 1995 dalam Lee, 2009 pada Komaba Journal of English Education). Kegiatan ini bertujuan untuk mengembangkan kegiatan menulis peserta didik dan meningkatkan motivasi peserta didik. Jangan sampai kegiatan ini 
malah disalahartikan seperti pada penelitian (Guénette, 2007), berpendapat bahwa sementara siswa dari kelompok yang lebih tinggi mencapai dengan merespon positif dan manfaat darifeedback guru, sedangkan siswa kelompok rendah sebaliknya merespon buruk dan terus-menerus harus didorong untuk memahami komentar guru.

Agar tidak terjadi hal tersebut, peneliti akan mencoba seperti yang telah diungkapkan Hyland \& Hyland (2001) di atas, teknik peer feedback ini akan diujicobakan pada kegiatan menulis bahasa Jepang dan lebih difokuskan pada kelompok mahasiswa berkemampuan rendah.

Berdasarkan hasil analisis data yang dilakukan pada penelitian sebelumnya (Sutjiati \& Rasiban, 2016) menunjukkan bahwa mayoritas mahasiswa semester 4 Departemen Pendidikan Bahasa Jepang (DPBJ) FPBS UPI tahun akademik 2014/2015 kemampuan menguasai pola kalimat dan tata bahasa bahasa Jepang tingkat menengah masih kurang. Dan perbendaharaan kosa kata yang dimilikinya pun sedikit.

Tetapi ada hal yang harus diperhatikan bahwa agar kegiatan tersebut dapat berkembang dan terarah perlu adanya kontrol dan evaluasi dari pengajar yaitu dengan memberikan respon berupa evaluasi dan feedback untuk mengembangkan daya kreatifitasnya.

Tetapi ada beberapa temuan yang didapat pada penelitian ini bahwa kegiatan umpan balik (feedback) yang diberikan oleh pengajar tidak dapat diberikan secara maksimal. Hal ini dikarenakan kegiatan tersebut dilakukan melalui dunia maya / online. Sedangkan pada dunia maya selalu saja dihantui oleh permasalahan koneksi internet yang tidak maksimal, sehingga komunikasi antar pengajar dan peserta didik terhambat kemudian kegiatan feedback pun tidak dapat dilakukan dengan baik. Untuk mengatasi hal ini, muncullah pertanyaan tentang apa yang akan menjadi pendekatan yang paling efektif untuk meningkatkan kemampuan menulis siswa dan pendekatan apa yang akan cocok dengan kebutuhan peserta didik tertentu.

Selama dua puluh tahun terakhir, studi pendidikan bahasa telah memberikan perhatian besar pada masalah bagaimana untuk memberikan umpan balik (feedback) untuk menulis siswa (Saito, 1994:46). Memberikan feedback tertulis yang efektif adalah salah satu tugas yang paling penting untuk guru 
menulis bahasa Inggris (Hyland, 1998; Hyland \& Hyland, 2001).

Banyak penelitian telah menunjukkan bahwa kegiatan feedback yang diberikan oleh pengajar dapat mengembangkan kegiatan menulis peserta didik (Ferris \& Roberts, 2001; Ferris, 2004; Goldstein, 2004; Zhang, 1995 dalam Lee pada Komaba Journal of English Education (2009)). Kegiatan ini bertujuan untuk mengembangkan kegiatan menulis peserta didik dan meningkatkan motivasi peserta didik. Jangan sampai kegiatan ini malah disalahartikan seperti pada penelitian (Guénette, 2007), berpendapat bahwa sementara siswa dari kelompok yang lebih tinggi mencapai dengan merespon positif dan manfaat dari feedback guru, sedangkan siswa kelompok rendah sebaliknya merespon buruk dan terusmenerus harus didorong untuk memahami komentar guru.

Agar tidak terjadi hal tersebut, peneliti akan mencoba seperti yang telah diungkapkan Hyland \& Hyland (2001) di atas, teknik peer feedback ini akan diujicobakan pada kegiatan menulis bahasa Jepang dan lebih difokuskan pada kelompok mahasiswa berkemampuan bahasa Jepang kurang baik.

Berdasarkan identifikasi masalah tersebut di atas, pada penelitian ini terdapat masalah pokok yang perlu diidentifikasi dan dirumuskan berkaitan dengan kegiatan menulis dalam bahasa Jepang tingkat menengah dengan menerapkan model pembelajaran teknik Peer Feedback. Pokok permasalahan dalam penelitian ini sebagai berikut, (1) Bagaimana hasil menulis tingkat menengah (Chukyu Sakubun 2) mahasiswa setelah menggunakan model pembelajaran Peer Feedback?; (2) Bagaimana pengaruh model pembelajaran Peer Feedback dalam meningkatkan kemampuan menulis bahasa Jepang tingkat menengah?; (3) Bagaimana tanggapan mahasiswa terhadap penggunaan model pembelajaran Peer Feedback dalam perkuliahan menulis tingkat menengah (Chukyu Sakubun 2) ?

Berdasarkan pertanyaan penelitian yang telah dijelaskan sebelumnya, tujuan dari penelitian ini adalah sebagai berikut, (1) untuk mengetahui kemampuan menulis mahasiswa setelah menggunakan model pembelajaran Peer Feedback; (2) untuk mengetahui pengaruh model 
pembelajaran Peer Feedback dalam meningkatkan kemampuan menulis bahasa Jepang tingkat menengah; (3) untuk menghimpun pendapat dan respon mahasiswa terhadap penggunaan model pembelajaran Peer Feedback dalam perkuliahan menulis tingkat menengah.

Teknik Peer Feedback atau Umpan Balik adalah praktik dalam pendidikan bahasa di mana umpan balik diberikan oleh satu siswa ke siswa lainnya. Umpan balik rekan sebaya digunakan dalam menulis kelas bahasa pertama dan bahasa kedua untuk memberi siswa lebih banyak kesempatan untuk belajar satu sama lain (https://en.wikipedia.org/wiki/ Peer feedback). Menurut Hyland (2005:198) (dalam Mubarok, 2012) Peer Feedback merupakan pendekatan dimana dimensi sosial dibuat di kelas menulis, berdasarkan asumsi bahwa menulis adalah proses sosial. Strategi peer feedback memungkinkan siswa untuk menegosiasikan gagasan mereka, memberi komentar dan memperbaiki kesalahan terhadap hasil karangan rekan mereka, dan memberikan saran untuk pengembangan draf rekan mereka. Oleh karena itu, peer feedback menjadi strategi alternatif dalam penulisan pengajaran yang bisa diterapkan untuk meningkatkan kemampuan menulis siswa.

Umpan balik adalah elemen fundamental dari pendekatan proses penulisan (Keh, 1990: 294). Hal ini dapat diartikan sebagai masukan dari pembaca kepada penulis dengan memberikan informasi kepada penulis untuk direvisi. Dengan kata lain, itu adalah komentar, pertanyaan, dan saran, pembaca memberi kepada penulis untuk menghasilkan tulisan yang bagus. Menulis bisa menjadi sarana untuk mengembangkan gagasan, merumuskan kembali pengetahuan dan menemukan pengalaman pribadi. Menurut Ferris and Hedgcock (2005: 225) ZPD ( Zone of Proximal Development) adalah salah satu teori Vygotsky yang mendukung peer feedback. Teori ini menjelaskan mengapa dan bagaimana kemampuan menulis siswa dapat dikembangkan melalui umpan balik rekan.

Umpan balik tampaknya sama pentingnya dengan proses belajar mengajar sebagai revisi terhadap proses penulisan (Dheram (1995: 160) dalam Mubarok (2012)). Oleh karena itu penting untuk mengembangkan 
kesadaran akan sifat dan fungsi umpan balik sehingga guru dan peserta didik dapat menjalankan perannya secara efektif di mata kuliah Menulis.

Dari beberapa penelitian tindakan kelas (PTK) yang telah dilakukan selama ini khususnya mengenai permasalahan dalam keterampilan menulis sebagai berikut, Siklus 1 dengan teknik pembelajaran Peer Review (Rasiban, 2014); Siklus 2 memperbaiki model pembelajaran dari evaluasi siklus 1 yaitu dengan menggunakan teknik pembelajaran berbasis Proyek Respons Kreatif (PRK) dengan tujuan untuk meningkatkan kreatifitas menulis karangan dalam bahasa Jepang (Rasiban, 2015); dilanjutkan pada Siklus 3 berdasarkan dari feedback siklus 2 yaitu mengubah sedikit model pembelajaran yaitu menggunakan model pembelajaran berbasis Project Based-Learning (PBL) (Sutjiati \& Rasiban, 2016).

Berdasarkan hasil penelitian yang didapat pada siklus 3, kemampuan mahasiswa dalam menemukan ide dan mengembangkan isi karangan sudah teratasi dengan teknik PRK dan PBL. Tetapi ternyata tidak hanya berhenti dalam tahap tersebut. Muncul problem baru yaitu bagaimana meningkatkan kemampuan menulis dan mengembangkan isi karangan yang berkualitas. Sedangkan waktu perkuliahan tidak memadai. Oleh karena itu akan diterapkan model pembelajaran menulis dengan teknik peer feedback.

Penelitian mengenai teknik Peer Feedback sudah banyak, tetapi pada penelitian ini akan mengacu pada penelitian terdahulu Saito (1994); Hyland \& Hyland (2001); Lee (2009) dan Mubarok (2012).

2.3 Intermediate Writing Learning Model with Peer Feedback Tehnique Menulis adalah kegiatan produktif dan ekspresif (Tarigan dalam Abidin, 2009, hlm. 98). Keterampilan menulis dalam bahasa Jepang dapat digolongkan ke dalam tiga macam (Sutedi, 2009), yaitu:

1) menulis huruf (kana dan kanji)

2) menulis kalimat (bunsaku); dan

3) menulis cerita atau karangan (sakubun)

Kegiatan menulis pada penelitian ini difokuskan pada kegiatan menulis karangan (sakubun) sehingga sampel penelitian melakukan 
kegiatan mengarang dalam setiap treatment dengan tema dan jenis karangan yang bervariasi. Seperti yang telah diungkapkan oleh Hyogyon (2010) bahwa menulis merupakan sebuah proses memiliki beberapa tahapan yang harus dilalui. Tahapan-tahapan dalam menulis dapat dibagi menjadi tiga bagian (Akhadiah dkk., 1988:2), yaitu:

- Tahap pra penulisan yang meliputi topik penulisan, pembahasan topik, menentukan tujuan penelitian, menentukan bahan atau materi penulisan, menyusun kerangka karangan.

- Tahap penulisan yang meliputi memilih kata-kata yang dapat dirangkai menjadi kalimat-kalimat yang efektif. Kemudian kalimat-kalimat tersebut harus disusun menjadi paragraf-paragraf yang memenuhi persyaratan. Selain itu ejaan dan tanda baca dalam penulisan pun perlu diperhatikan.

- Tahap revisi yang dilakukan dengan cara meneliti secara keseluruhan mengenai logika, sistematika, ejaan, tanda baca, pilihan kata, kalimat, paragraf, dan lain-lain.

Dalam pendekatan proses lebih ditekankan kepada bagaimana responden menuangkan gagasan menjadi sebuah tulisan. Setelah mendapat feedback dari guru dan teman berupa coretan-coretan perbaikan, responden menulis dan memperbaiki kembali hasil tulisannya itu. Begitu seterusnya sampai tulisan itu layak dianggap sebagai tulisan (Alwasilah, 2005:44).

Model pembelajaran yang menjadi objek penelitian ini mengacu pada pembelajaran menulis dengan teknik kolaboratif sehingga dalam proses pembelajaran mahasiswa melakukan kegiatan pembelajaran secara aktif dan mandiri (student center) tidak terpusat pada dosen/pengajar (teacher center). Dan yang menjadi ciri khas dalam pembelajaran menulis dengan pendekatan kolaboratif ini adalah adanya umpan balik yang diberikan langsung oleh mahasiswa kepada mahasiswa lain. Sehingga kegiatan koreksi hasil tulisan/ karangan dapat tersampaikan secara langsung kepada penulis tidak seperti pembelajaran menulis biasanya yang hanya mengandalkan pemberian umpan balik dari dosen/pengajar yang diberikan secara tidak langsung di kelas.

Akan tetapi dalam teknik kolaboratif ini, mahasiswa dapat mengetahui secara langsung kekuatan dan kelemahan dari tulisannya. Karena teman yang 
menjadi korektor menyampaikan secara langsung hal-hal yang menjadi kelebihan dan kekurangan dari hasil karangan yang dibuat melalui saran dan komentar serta feedback.

Hal inilah yang membuat menulis sulit sekali dikembangkan oleh mahasiswa. Berdasarkan hasil angket yang disebarkan pada responden menunjukkan bahwa sebagian besar mahasiswa sebanyak 70\% menganggap hal yang paling sulit dalam menulis/mengarang adalah mengembangkan ide cerita menjadi satu cerita utuh. Sesuai dengan pendapat Hyogyon (2010:4) bahwa menulis merupakan proses dalamberkomunikasi.

Yang membedakan kegiatan menulis dengan kegiatan berbicara adalah lawan bicara yang dihadapi tidak secara langsung, sehingga respon yang didapat tidak secara langsung juga. Kita dibuat menyelesaikan sebuah tulisan tanpa melihat respon lawan bicara. Dengan kata lain, kegiatan menulis adalah proses menulis sambil berpikir untuk menyampaikan sesuatu pesan kepada lawan bicara tanpa mengetahui reaksi lawan bicara (Hyogyon, 2010).

Berdasarkan teori tersebut, hasil observasi yang dilakukan pada perkuliahan Chuukyuu Sakubun 2 (menulis tingkat menengah) pada tingkat 2 semester 4 pun menunjukkan hal yang sama. Walaupun mahasiswa telah diberi tema kemudian distimulus dengan memberikan latihan pola kalimat yang akan muncul pada karangan/tulisan, lalu diberikan kerangka karangan/ berpikir, tetap saja isi tulisan /karangan apabila tidak dipaksakan, tidak bisa berkembang.

Pada studi pendahuluan yang telah dilakukan sebelum kegiatan eksperimen menunjukkan apabila kegiatan menulis/mengarang diberikan waktu 40 menit, hanya $30 \%$ responden saja yang bisa menyelesaikan satu karangan/tulisan utuh maksimal sampai 3 paragraf(Sutjiati \& Rasiban, 2016). Sebagian besar lainnya rata-rata hanya mampu menuliskan 1 paragraf saja. Hal ini menunjukkan bahwa mahasiswa masih belum mampu dan merasa kesulitan dalam mengembangkan ide cerita ke dalam bentuk karangan/ tulisan.

Hal ini sejalan dengan hasil angket (April 2017) yang dihimpun bahwa faktor yang membuat sulit dalam mengembangkan karangan/tulisan 
adalah $65 \%$ menjawab pemilihan dan penguasaan kosa kata, kemudian $25 \%$ penguasaan struktur pola kalimat dan $10 \%$ kurangnya penguasaan antar koherensi kalimat.

Target yang ingin dicapai pada perkuliahan Chuukyuu Sakubun 2 ini adalah mahasiswa mampu menuliskan sebuah karangan / tulisan berdasarkan tema sehari-hari dengan pola kalimat yang telah dipelajari pada semester sebelumnya dalam tingkat kemampuan bahasa Jepang level menengah.

Pada kenyataannya, sudah banyak strategi / teknik yang ditawarkan untuk meningkatkan kemampuan menulis diantaranya yang menggunakan teknik Peer Learning. Oleh karenanya, tanggung jawab pengajar sebagai pendidik dalam memberi pemahaman konsep menulis pada mahasiswa perlu ditingkatkan lagi. Sejalan dengan pendapat Kimura Muneo (1998) salah satu faktor yang memegang peranan penting diantara faktor-faktor yang ada adalah pengajar. Selain faktor materi, pembelajar, dan faktor eksternal lainnya, semua hal tersebut akan sangat bergantung kepada kreativitas pengajar. Dedikasi dan kemampuan pengajarlah yang pada akhirnya mempengaruhi pelaksanaan kegiatan belajar mengajar.

Oleh karena itu, untuk menyikapi permasalahan yang menghambat dalam kegiatan menulis berbahasa Jepang dan untuk meningkatkan kualitas isi karangan digunakan teknik Peer Feedback. Teknik ini berpusat pada kerjasama antar tutor sebaya atau disebut teman/partner dalam kegiatan menulis untuk menyempurnakan hasil tulisannya melalui evaluasi / feedback. Responden tidak hanya memberikan feedback saja, lebih dari itu, juga ada kegiatan mereviu karangan teman lalu memberikan kritik, saran dan sebagainya.

Sama halnya dengan teknik Peer Review pada awal pembelajaran pengajar melakukan brain storming terhadap materi pembelajaran agar mahasiswa memahami maksud dan tujuan pembelajaran. Kemudian menampilkan power point yang berisi materi pembelajaran mengenai materi yang akan disampaikan dalam bahasa Jepang meliputi struktur, bahasa dan kosakata yang digunakan. Kemudian diakhir penjelasan menampilkan output karya tulisan/karangan dalam bahasa Jepang. tahapan berikutnya ada sesi 
Tanya jawab, kemudian latihan membuat kalimat dengan menggunakan pola kalimat yang akan muncul dalam materi yang dibahas.

Setelah itu mahasiswa diberikan 3 lembar kerja, yaitu lembar kerja (Work Sheet) yang digunakan untuk menuliskan karya tulisan dalam setiap pertemuan. Kemudian lembar penilaian (Review Sheet) yang digunakan untuk menilai hasil karya teman sejawat dan evaluasi berupa tanggapan dan penilaian terhadap hasil tulisan yang dikerjakan teman sebaya. Dan lembar kerja hasil revisi (Kakinaosi Sheet) yang digunakan untuk menuliskan kembali hasil revisi tulisan dari masukan / review teman sejawat. Pada tahapan inilah penerapan teknik Peer Review digunakan.

Pada kegiatan awal, responden masih merasa kesulitan dalam mengembangkan tema / ide cerita untuk menjadi sebuah tulisan karena diberi batasan waktu hanya 30 menit. Tapi setelah pertemuan kedua dan berikutnya responden tidak mengalami masalah. tahapan berikutnya adalah saling memberikan koreksi atau feedback/review ini dilakukan selama 15 menit. Hasil reviu dituliskan pada lembar kerja feedback (Feedback Sheet) diberikan kepada masing-masing mahasiswa kemudian melakukan diskusi secara langsung mengenai isi karangan sehingga penulis dapat memberikan tanggapan secara langsung dari hasil feedback tersebut.

Hasil feedback diberikan secara tertulis pada bagian lembar kerja (Feedback Sheet). Penilaian hasil feedback yang diberikan sebagian besar terletak pada tata bahasa (bunpou) yang meliputi penggunaan pola kalimat dan partikel. Kemudian karena dalam poster ini dianjurkan menggunakan gambar, banyak dari mahasiswa yang memberikan komentar terhadap kejelasan gambar yang dibuat temannya dan penggunaan kosakata yang dipilih.

Selama kegiatan peer feedback berlangsung pengajar melakukan pengawasan dan bimbingan kepada setiap kelompok agar kegiatan menjadi terarah dan sesuai dengan prosedur yang berlaku. Dari hasil pengamatan, pada kegiatan peer feedback sebagian besar mahasiswa dapat memberikan koreksi secara objektif, tetapi masih belum yakin / percaya diri akan kemampuan tata bahasa yang dimilikinya, sehingga mayoritas hanya mengoreksi tata bahasa, 
pola kalimat dan kosa kata level dasar saja. Namun masih ada beberapa mahasiswa yang mengalami kebingungan dalam memberikan koreksi karena keseluruhan isi karangan belum dapat dimengerti, serta dalam penulisan kanjinya.

\section{Metode Penelitian}

Pada penelitian ini menggunakan metode penelitian tindakan kelas (Classroom Action Research). Penelitian Tindakan Kelas merupakan penelitian yang permasalahannya dari konteks kelas (Susanto, 2010:7). Alasan menggunakan metode ini karena mata kuliah menulis tingkat menengah (Chuukyuu Sakubun) adalah mata kuliah yang diampunya. Penelitian PTK ini sudah memasuki siklus ke-4 dalam rangkaian roadmap penelitian Peer Learning KBK Pengajaran bagian kelompok keterampilan menulis.

Penelitian ini adalah penelitian tindakan kelas memasuki siklus 4, karena hasil dari siklus yang ketiga masih belum dapat menjawab pertanyaan penelitian. Rancangan/desain penelitiannya dapat digambarkan sebagai berikut,

\section{Gambar 1. Desain Penelitian}

\section{Siklus \#3}

\section{Model pembelajaran Menulis (Sakubun) dengan menggunakan} teknik Project Based Learning(PBL)

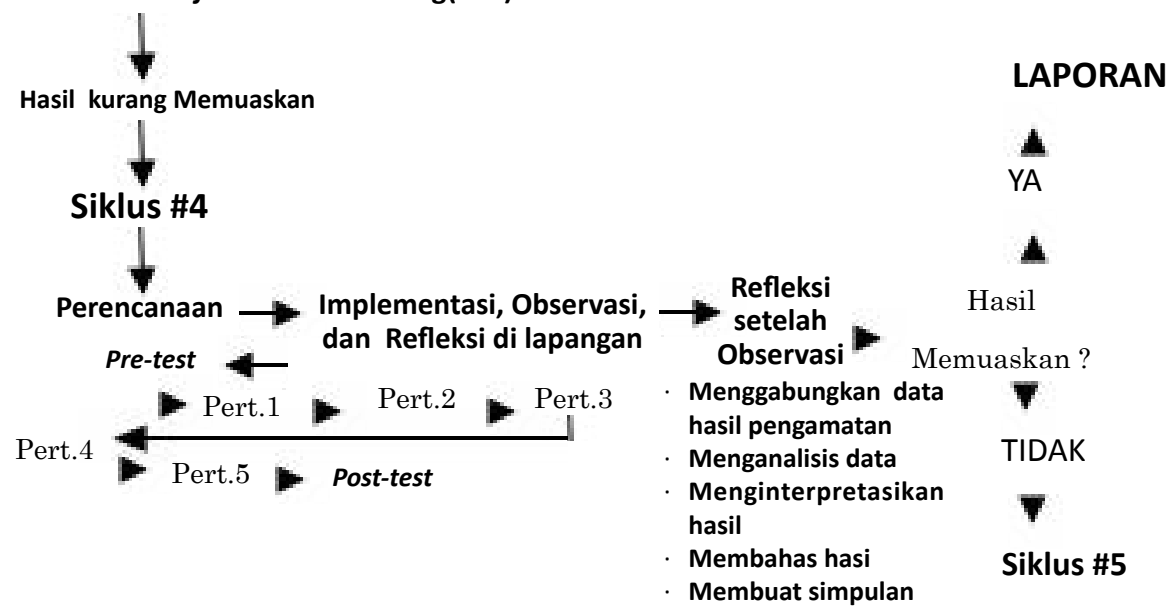


Partisipan dalam penelitian ini adalah mahasiswa tingkat 2 semester 4 Jurusan Pendidikan Bahasa Jepang FPBS UPI tahun akademik 2016/2017. Sampel dari penelitian ini diambil dari mahasiswa yang sedang mengambil mata kuliah Chuukyuu Sakubun 2 dengan jumlah sebanyak 20 orang.

Penelitian ini dilakukan pada semester genap tahun akademik 2016/2017. Penelitian ini dibagi menjadi tiga tahapan, yaitu tahapan persiapan, dilaksanakan di Departemen Pendidikan Bahasa Jepang FPBS UPI. Waktu pelaksanaannya dua bulan, dari bulan Maret sampai dengan bulan April 2017. Tahapan kedua yaitu tahap pelaksanaan dilakukan selama dua bulan, dari bulan Mei sampai bulan Juni 2017. Tahap ketiga yaitu tahap refleksi dan publikasi dilaksanakan selama dua bulan, yaitu bulan Juli dan Agustus 2017. Pada tahapan ini mengevaluasi kegiatan pada tahap sebelumnya. Kemudian menganalisis hasil yang dperoleh pada tahap pelaksanaan. Hasil tersebut disimpulkan hingga dibuat suatu laporan.

\section{Hasil dan Pembahasan}

Data yang diperoleh dalam penelitian ini didapat dari hasil analisis data mengenai data proses dan hasil pembelajaran menulis tingkat menengah bahasa Jepang yang disebut dengan mata kuliah Chuukyuu Sakubun 2 melalui pengamatan observer, proses pembelajaran menulis di kelas dengan menggunakan teknik Peer Feedback oleh tim peneliti, serta hasil nilai pre-test dan post-test.

Penelitian ini dilakukan 5 kali pertemuan diantaranya pertemuan pertama mengadakan pre-test untuk mengetahui kemampuan awal responden dan memberikan angket awal. Kegiatan ini dilakukan pada saat diawal perkuliahan dengan menggunakan tema sesuai dengan buku ajar yang digunakan pada perkuliahan Chuukyuu Sakubun 2. Pertemuan kedua sampai keempat pembelajaran Chuukyuu Sakubun 2 dengan menggunakan Teknik Peer Feedback. Dan pertemuan terakhir mengadakan post-test untuk mengetahui perbedaan hasil pembelajaran dengan membandingkan hasil ujian pada pre-test serta memberikan angket akhir 
Pada kegiatan treatment dengan menggunakan teknik Peer Feedback tema yang digunakan adalah (1) Watashi no Machi; (2) Saikin Nyuusu. Dari setiap pertemuan pada kegiatan treatment penilaian dan evaluasi diambil dengan cara menganalisis lembar kerja yang diberikan pada setiap pertemuan. Hasilnya adalah sebagai berikut,

\section{Hasil Analisis Data}

Dari hasil enam kali pertemuan yang telah dijelaskan di atas, dapat diamati bahwa kemampuan menulis karangan bahasa Jepang mahasiswa mengalami cukup peningkatan terutama pada bagian proses kegiatan menulis. Dalam hal mengembangkan tema menjadi suatu karangan pun dinilai ada peningkatan, bahkan muncul kreativitas mahasiswa lebih beragam. Hal ini dipengaruhi oleh teknik yang telah diterapkan pada siklus sebelumnya yaitu teknik Project Based Learning.

Berdasarkan hasil pengamatan observer pun dinilai positiftermasuk dalam segi pembelajaran dari awal kegiatan sampai akhir penyelesaian. Tapi ada beberapa temuan yaitu ada beberapa mahasiswa yang kurang aktif dalam pembelajaran padahal kegiatan menulis dikembangkan dalam kegiatan kelompok.

Nilai rata-rata mahasiswa dari nilai pre-test terdapat 5 orang mahasiswa (25\%) memiliki kemampuan baik secara tata bahasa dan kalimat pertemuan kedua sampai keempat pelaksanaan treatment selalu berada di atas nilai $80 ; 12$ orang mahasiswa $(60 \%)$ memiliki nilai antara $70-60$, dan 3 orang mahasiswa (15\%) memiliki nilai dibawah 60 . Hasil pre-test dapat disimpulkan bahwa kemampuan mahasiswa dalam mengembangkan karangan menjadi tulisan dapat dikatakan masih kurang. Karena yang mendapatkan nilai dibawah 70 sebanyak $75 \%$.

Setelah diadakan treatment dan setiap pertemuan selalumengadakan feedback antar teman sebaya, hasil karangan perbaikan mahasiswa selalu mengalami perkembangan karena telah diberikan koreksi berupa review, komentar, dan saran oleh teman yang menjadi peer sehingga mahasiswa menambahkan hasil koreksi tersebut pada karangan perbaikan. 
Dari hasil empat kali pelaksanaan treatment dapat diketahui bahwa nilai rata-rata mahasiswa pada pre-tes yaitu 67. Akan tetapi pada post-test mengalami peningkatan hingga mencapai rata-rata 80,1. Mahasiswa yang mendapatkan nilai dibawah 70 hanya ada 5 orang (25\%), dan sisanya sebanyak 15 orang $(75 \%)$ nilai posttestnya meningkat diatas 75 - 90 .

Jadi dapat disimpulkan model pembelajaran dengan menggunakan teknik Peer Feedback dapat memberikan pengaruh yang cukup berarti pada perkuliahan Chuukyuu Sakubun (menulis tingkat menengah).

\section{Hasil Analisis Data Angket}

Hasil wawancara dan angket yang dihimpun dari responden menunjukkan bahwa seluruh responden mengakui bahwa teknik Peer Feedback dapat membantu dan mempermudah responden dalam kegiatan menulis terutama dalam meningkatkan kualitas isi karangan ke dalam tulisan menarik seperti artikel majalah dinding dan poster.

Sebagian besar responden (85\%) menyatakan ada perkembangan terhadap pengembangan karangan, isi materi karangan. Lebih dari setengah jumlah responden (75\%) menanggapi positif dari model pembelajaran Peer Feedback, karangan dalam menyelesaikan suatu proyek tulisan dapat dilakukan secara berkelompok, jadi dapat saling melengkapi dari segi ide / tema, merangkai kalimat sampai mengembangkan isi tulisan.

Dari hasil wawancara secara mendalam kepada responden ditemukan bahwa mahasiswa mengalami kesulitan pada alokasi waktu yang telah ditentukan dalam menulis karangan sehingga karangan belum selesai. Selain itu, temuan mendasar dari hasil wawancara didapat bahwa hampir setengah dari jumlah seluruh responden merasa bahwa metode peer feedback menimbulkan rasa ketidakpercayadirian responden dalam memberikan feedback kepada temannya. Mayoritas menjawab bahwa tidak percaya diri atas kemampuan tata bahasa, penguasaan kosa kata dalam bahasa Jepang. Jadi apa yang mereka berikan dalam feedback selalu ada kekhawatiran salah mengoreksi. Sehingga yang dicek hanya kosa kata yang diketahui dan dikenalinya saja, begitu pula tata bahasa juga hanya koreksian tata bahasa level dasar saja. 
Ada beberapa kelemahan dari Peer Feedback yang hampir mirip dengan kelemahan Peer-Review (Rasiban, 2014) adalah banyak dari reviewer tidak mempunyai cukup waktu untuk melakukan reviu secara teliti. Sehingga menyebabkan sedikit sekali orang yang melakukan reviu yang baik. Hal ini dikarenakan skema pengetahuan yang dimiliki tentang materi baik penguasaan kosa kata, pola kalimat dan materi yang dimiliki responden beragam.

Tetapi kelemahan dari teknik ini dapat diminimalisir dengan adanya kehadiran dosen sebagai evaluator dan fasilisator untuk mereviu ulang hasil reviu yang dilakukan oleh responden. Kemudian tahapan berikutnya adalah mengadakan feedback materi di awal pertemuan oleh dosen sebagai pengajar. Hal ini bertujuan untuk mengurangi kesalahan agar tidak dilakukan secara berulang oleh responden yang lainnya terutama dalam .hal tata bahasa, pola kalimat dan pemilihan kosa kata yang tepat.

\section{Simpulan}

Berdasarkan hasil penelitian yang sudah dipaparkan sebelumnya, disimpulkan bahwa feedback dari teman sebaya tentang menulis sebuah karangan dalam bahasa Jepang dapat mengembangkan siswa untuk meningkatkan pengetahuan mereka melalui pemberian kesempatan untuk berpikir kritis, dan untuk meningkatkan ilmu otonomi mereka. Dengan kata lain bahwa peer feedback digunakan untuk mengambil bagian penting dalam menulis karena instruksi kegiatan ini menyediakan platform fleksibel untuk membantu praktik penulisan mahasiswa (Bijami dkk, 2013).

Temuan yang muncul dari kegiatan eksperimen ini adalah masih banyak mahasiswa yang merasa tidak yakin / tidak percaya diri akan kemampuannya terutama dalam mengoreksi atau menilai hasil karangan temannya, baik dalam mengoreksi dari segi tata bahasa, pola kalimat dan pemilihan kosa kata yang tepat. Selain itu, ada beberapa mahasiswa di kelompok rendah yang kurang menguasai huruf kanji. Sehingga pada saat membaca hasil karangan temannya merasa kesulitan bahkan tidak tahu maknanya. Hal inilah yang menghambat pada kegiatan tahap akhir. Oleh 
karena itu, diperlukan fungsi pengajar untuk melakukan feedback secara keseluruhan pada akhir pertemuan.

Teknik Peer Feedback telah dianjurkan dalam beberapa penelitian untuk sejumlah manfaat. Misalnya, Hyland (2000) dalam Bijami, Kashef \& Nejad (2013) menyebutkan bahwa peer feedback mendorong mahasiswa untuk berpartisipasi dalam aktivitas kelas dan melatih mereka untuk tidak bergantung pada guru / pengajar secara pasif. Selain itu, menggunakan peer feedback dapat mengurangi rasa ketakutan dalam penulisan dan lebih percaya diri sekaligus membangun konteks sosial dalam menulis. Yang et al., (2006) dalam Bijami, Kashef \& Nejad (2013) juga menambahkan bahwa peer feedback bermanfaat dalam mengembangkan pemikiran kritis, otonomi peserta didik dan interaksi sosial antar mahasiswa. Lebih penting lagi, latihan peer feedback memungkinkan mahasiswa untuk menerima lebih banyak komentar dari individu dan juga memberi kesempatan kepada para pengulas untuk mempraktekkan dan mengembangkan kemampuan bahasa yang berbeda (Lundstrom dan Baker, 2009).

\section{Ucapan Terima Kasih}

Tim Peneliti mengucapkan terima kasih kepada para mahasiswa tingkat 2 semester 4 Jurusan Pendidikan Bahasa Jepang FPBS UPI tahun akademik 2016/2017. Dan terutama kepada Universitas Pendidikan Indonesia sebagai pemberi dana hibah Pembinaan dan Pengembangan Kajian Bidang Keilmuan (PPKBK) tahun anggaran 2017 atas dukungannya untuk kelancaran kegiatan penelitian ini.

\section{Daftar Pustaka}

Akhadiah, Sabarti, dkk. 1988. Pembinaan Kemampuan Menulis Bahasa Indonesia. Jakarta: Erlangga.

Alwasilah, A. Chaedar \& Senny, S.A. 2005. Pokoknya Menulis. Bandung: PT Kiblat Buku Utama. 
Amanda, Raysha. 2013. Efektivitas Model Proyek Respons Kreatif dalam Meningkatkan Keterampilan Menulis Karangan Bahasa Jepang. (Skripsi). Fakultas Pendidikan Bahasa dan Sastra, Universitas Pendidikan Indonesia, Bandung.

Bijami, Maryam; Kashef, Seyyed Hosein \& Nejad, Maryam Sharafi. 2013. Peer Feedback in Learning English Writing: Advantages and Disadvantages. Journal of Studies in Education, Vo.3 No.4, 2013. Celce, M. - Murcia and Elite Olstain. 2000. Discourse and Context in Language Teaching. New York: Cambridge University Press. Ferris, D.R., and Hedgcock, S. 2005. Teaching ESL Composition: Purpose, Process, and Practice. USA: Lawrence Elbaum Associates Publisher. Gie, L. 1992. Pengantar Dunia Karang Mengarang. Yogyakarta: Liberty. Guénette, D. 2007. Is Feedback Pedagogically Correct? Research Design Issues in Studies of Feedback on Writing. Journal of Second Language Writing, 16, p. 40-53.

Hyland, F. 1998. The Impact of Teacher Written Feedback on Individual Writers. Journal of Second Language Writing, 7(3), p. 255-286. Hyland, F., \& Hyland, K. 2001. Sugaring the pill: Praise and Criticism in Written Feedback. Journal of Second Language Writing, 10, p.185-212.

Hyogyon, Kimu. 2010. Kaku koto o oshieru. Tokyo: The Japan Foundation. Keh, C. 1990. Feedback in the Writing Process: a Model and Methods for Implementation. ELT Journal. 44. (4): 294-304.

Lee, Nancy S. 2009. Written Peer Feedback by EFL Students: Praise, Critism and Suggestion. Komaba Journal of English Education, p.129-139. [Diakses dari http://park.itc.u-tokyo.ac.jp/ eigo/KJEE/001/ 129-139.pdf. 11 Februari 2017]

Mubarok, Husni. 2012. The Use of Peer Feedback Strategy to Motivate Students in Narrative Text Writing. English Education Journal 2(2012), p.162-168. [Diakses dari http://journal.unnes.ac.id/sju/index. ph/eej._11 Februari 2017] 
Rasiban, Linna M. 2014. Model Pembelajaran Peer Review dalam Meningkatkan Kemampuan Menulis. Jurnal Kajian Bahasa dan Pariwisata BARISTA, Vol.1 No. 1 hlm.116-125.

Rasiban, Linna M. 2015. Upaya Meningkatkan Kreatifitas Menulis

Karangan Bahasa Jepang Melalui Model Pembelajaran Berbasis

Proyek Respons Kreatif. Jurnal Pendidikan Bahasa Jepang ASPBJI

Korwil Jabar "Wa” Vol.8 No.2. Desember 2014.

Saito, Hiroko. 1994. Teachers' Practices and Students' Preferences for Feedback on Second Language Writing: A Case Study of Adult ESL Leaners. TESL Canada Journal Vol.11 No.2, Spring 1994, p.46-70.

Susanto. 2010. Konsep Penelitian Tindakan Kelas dan Penerapannya.

Surabaya : Unesa.

Sutedi, Dedi. 2009. Penelitian Pendidikan Bahasa Jepang. Bandung: Humaniora Utama Press.

Sutjiati, Neneng \& Rasiban, Linna M. 2016. Project-Based Learning sebagai Upaya Meningkatkan Kreatifitas Menulis Karangan Pendek Bahasa Jepang. Jurnal Kajian Bahasa dan Pariwisata BARISTA Vol.4, No.2, Desember 2017.

Tarigan, Henry G. 2008. Menulis sebagai Suatu Keterampilan Berbahasa. Bandung : Angkasa. 